Diskusia/ Discussion

Recenzované/ Review: 20. 12. 2021

https://doi.org/10.24040/eas.2021.22.2.51-66

\title{
Súčasné problémy rozvoja biosférických rezervácií v Slovenskej republike
}

Current problematic issues of biosphere reserves in Slovak Republic

\section{Katarína Vitálišová, Lucia Miňová, Anna Vaňová}

Abstract: The systematic development of biosphere reserves belongs to the challenges of Agenda 2030 and is crucial to eliminate the consequences of climate changes and support the sustainability and resilience of territory. The aim of the paper is to define the fundamentals of the biosphere reserves in the Slovak Republic and to characterize the problem areas of their operating. Based on the theoretical definition of biosphere reserves the paper discusses the main challenges and obstacles in management of four biosphere reserves in Slovak Republic the Slovak Karst, Pol'ana, Eastern Carpathians a Tatras. The information and data were collected by the interviews with the representatives of biosphere reserves and the Head of Slovak Committee for MAB.

Key words: Biosphere reserves. Development. Stakeholders. Agenda 2030.

JEL Classification: Q01. Q56.

\section{Úvod}

Súčasné zmeny vo svete spojené s negatívnymi dopadmi na životné prostredie výrazne ovplyvňujú zachovanie biodiverzity, teda rozmanitosti sveta prírody. Ide o jeden z kl'účových ciel'ov Agendy 2030, konkrétne štrnásty (,zachovat' a trvalo udržatel'ne využívat' oceány, moria a zdroje mora na trvalo udržatel'ný rozvoj“") a pätnásty ciel' (,chránit', obnovovat' a podporovat' udržatel'né využívanie ekosystémov, udržatel'ne riadit' lesné hospodárstvo, bojovat' proti znehodnocovaniu pôdy a zastavit' stratu biodiverzity”), ktoré sú úzko prepojené so všetkými ostatnými ciel'mi trvalo udržatel'ného rozvoja. Udržanie odolných ekosystémov a ich služieb (napr. dostupnost' pitnej vody, potravín, úrodnost' pôdy, regulácia klímy, estetické hodnoty a pod.) a ochrana biodiverzity našej planéty sú základom boja proti chudobe, za l’udské zdravie, a dobré životné podmienky. Biodiverzita ako taká podporuje väčšinu ciel’ov trvalo udržatel'ného rozvoja a jej strata predstavuje hrozbu pre bezpečnost' aj mier (UNESCO, 2021). 
Pre zachovanie biodiverzity je nevyhnutné pochopit' vzájomné súvislosti medzi jej podstatou, kultúrnou rozmanitost'ou, spoločenskými aspektmi a etickými otázkami

Jedným z hlavných predstavitel'ov biodiverzity v priestorovom kontexte sú biosférické rezervácie (rezervy biosféry). Ide o územia charakteristické suchozemskými, morskými alebo pobrežnými ekosystémami, rozvíjané s ciel’om zosúladenia ochrany biodiverzity a trvalej udržatel’nosti (Fabriciusová, Miňová, 2016). Problematika biosférických rezervácií a ich rozvoja je v podmienkach Slovenskej republiky podceňovaná a nedostatočne profesionálne podporovaná. V slovenskej odbornej ani vedeckej literatúre nie sú dostupné informácie, a ani vymedzenie problematiky biosférických rezervácií, resp. relevantné výskumy súvisiace s touto problematikou z pohl'adu ich strategického rozvoja. Preto je ciel’om príspevku definovat' podstatu a špecifiká biosférických rezervácií v Slovenskej republike a charakterizovat' problémové oblasti ich fungovania.

\section{Biosférické rezervácie a ich rozvoj}

Biosférické rezervácie sú medzinárodne uznávané ako modelové územia vykonávajúce praktickú aplikáciu interdisciplinárnych poznatkov s ciel'om pochopit' a udržat' vzt'ah medzi človekom a prírodou a koordinovat' zmeny, vrátane prevencie konfliktov a ochrany biodiverzity. Biosférické rezervácie, podobne ako pamiatky svetového dedičstva (kultúrne a prírodné), sú územia medzinárodného významu, ktoré vyhlasuje hlavný orgán UNESCO Programu Človek a biosféra - Medzinárodná koordinačná rada MAB (d’alej ICC MAB) (§ 28b ods. 1 Zákona č. 543/2002 o ochrane prírody a krajiny v znení neskorších právnych predpisov).

Biosférické rezervácie vznikli v 70. rokoch minulého storočia v rámci Programu UNESCO Človek a biosféra (MAB). S rozvojom medzinárodnej environmentálnej agendy v 90. rokoch 20. storočia bol v roku 1995 v španielskom meste Sevilla usporiadaný druhý medzinárodný kongres o biosférických rezerváciách, kde bola sformulovaná Sevillská stratégia, vrátane Sevillskej vízie pre 21. storočie, obsahujúca kl’účové aktivity pre implementáciu konceptu biosférických rezervácií a Štatutárny rámec Svetovej siete biosférických rezervácií.

Biosférické rezervácie predstavujú prístup manažmentu krajiny, ktorý harmonizuje vzt'ahy medzi l'ud'mi a prírodou. Zahŕňajú v sebe krajinu rôzneho charakteru vymedzenú geograficky (Batisse, 1985; UNESCO, 1996; Bridgewater, 2002). Ide o reprezentatívne územia s vlastnou úlohou a poslaním prospešným ako pre prírodu, tak pre človeka. Slúžia ako príklad udržatel'ného života, prijatel'nej rovnováhy a vzájomného vzt’ahu človeka s prírodným prostredím. Zohrávajú významnú úlohu nielen pre miestne obyvatel'stvo, ale aj pre celú spoločnost'. 
Svetovú siet’ biosférických rezervácií aktuálne tvorí 727 území v 131 krajinách sveta. Z celkového počtu je 22 cezhraničných biosférických rezervácií. Na základe rozhodnutia ICC MAB sa počty biosférických rezervácií každý rok menia (https://en.unesco.org/biosphere/wnbr, 2021).

Každá biosférická rezervácia má tri funkcie, a to: (a) ochrannú s dôrazom na ochranu na všetkých úrovniach, vrátane ochrany krajiny, ekosystémov, druhov a genetickej rôznorodosti; (b) rozvojovú, ktorá je zameraná na zabezpečenie hospodárskeho a l’udského rozvoja územia, ktorý je spoločensko-kultúrne a ekologicky udržatel'ný; (c) funkciu logistickej podpory zahŕňajúcu podporu názorných ukážkových projektov, environmentálneho vzdelávania a výchovy, výskumu a monitorovania vo vzt’ahu $\mathrm{k}$ miestnym, štátnym, regionálnym a svetovým problémom ochrany a trvalo udržatel’ného rozvoja (Vološčuk, 1998).

V zmysle Rámcového štatútu (2017) má každá biosférická rezervácia vytvorenú zonáciu územia, ktorá pozostáva z troch zón. Prvou je jadrová zóna, ktorá je v zmysle Zákona NRSR č. 543/2002 o ochrane prírody a krajiny v znení neskorších právnych predpisov chránená najprísnejším stupňom ochrany. Z hl'adiska prírodných hodnôt predstavuje najcennejšiu čast' územia, pričom sa v nej uprednostňuje zachovanie biologickej diverzity a monitorovanie takmer nenarušených ekosystémov. Zóna tiež prispieva k udržiavaniu funkcií ekosystému, medzi ktoré sa radí zachytávanie uhlíka, stabilizácia pôdy alebo zásobovanie pitnou vodou. V tejto časti biosférickej rezervácie sa nevykonávajú žiadne hospodárske aktivity, je ponechaná autoregulačným procesom a slúži na menej zatažujúce vzdelávanie a výskum. Opatrenia sa vykonávajú len po odbornom posúdení v prípadoch, ked' dôjde $\mathrm{k}$ narušeniu prírodnými živlami alebo ak ide o činnost', ktorá je nevyhnutná pre zabezpečenie starostlivosti o chránené územie. Jadrovú zónu obklopuje alebo tesne k nej prilieha jasne určená nárazníková zóna, ktorá znižuje pôsobenie l’udských aktivít a chráni jadrá biosférickej rezervácie pred okolitými vplyvmi. Hospodárenie je v týchto častiach podriadené záujmom ochrany prírody. Je nevyhnutná pre zachovanie biologickej a kultúrnej rozmanitosti. Nárazníková zóna plní úlohu biologického spojenia, ktoré funguje ako prirodzený koridor medzi jadrovou a prechodovou zónou. Tretím typom je prechodová zóna, ktorá je základom pre riadenie a udržatel’ný rozvoj prírodných zdrojov. V týchto častiach biosférickej rezervácie sa môže uskutočnit' ovel’a širšia škála hospodárskych činností, ktoré prinášajú prospech sociálno-ekonomickému rozvoju miestneho obyvatel'stva. Tieto činnosti však musia rešpektovat' konkrétne ciele každej biosférickej rezervácie (Fabriciusová, Slávik, 2010).

Rozvoj biosférickej rezervácie, predovšetkým ekonomicky a sociálny, sa preto spája najmä s prechodovou a nárazníkovou zónou. Pojem rozvoj v kontexte územného celku, ktorým je aj 
biosférická rezervácia, nie je v dostupnej literatúre jednoznačne definovaný. Buček (1992, s. 40) chápe rozvoj v najširšom zmysle ako "rozšírenie ekonomického systému pri zmenených a progresívnych parametroch rastových faktorov". V literatúre sa často stretávame s názorom, že pojem rozvoj dlhý čas splýval s pojmom hospodársky rast (chápe sa ako zvýšenie celkového produktu krajiny za určité obdobie) alebo tiež ekonomický rozvoj (znamená dlhodobé zvyšovanie ekonomického bohatstva krajiny). Daly a Cobb (In Švihlová, 2004, s. 12, 13) spresnili rozdiel medzi definovaním pojmov rast a rozvoj. Rast definovali ako kvantitatívne zväčšovanie ekonomického systému v rozsahu jeho fyzických dimenzií, zatial' čo rozvoj definovali ako kvalitatívnu zmenu fyzicky sa nezväčšujúceho ekonomického systému v dynamickej rovnováhe so životným prostredím. Aj napriek tomu, že pojmy rozvoj a ekonomický rast nie je možné vzájomne zamieňat', ich koexistencia a vzájomné prepojenie je nevyhnutnost'ou. Nohlen a Nuscheler (In Maier, Tödtling, 1997, s. 39) okrem ekonomického rastu zdôrazňujú úlohu d’alších faktorov, ktoré je potrebné rozvíjat' pre dosiahnutie rozvoja územia, akými sú práca, rovnost'/spravodlivost', participácia a nezávislost', čím sa pojem rozvoja rozširuje o kvalitatívnu stránku, ktorú predstavuje kvalita života, dodržiavanie l'udských práv, spravodlivost' v rozdel'ovaní dôchodkov a pod. Nevyhnutnou súčast'ou je pôsobenie verejnej správy najmä v oblasti regulovania vzt’ahov medzi aktérmi v území, ktoré sa vyvíjajú v prostredí charakterizovanom neoliberálnymi prístupmi (Čapková, 2004). S prístupom Nohlena a Nuschelera sa stotožňujeme a považujeme ho za vhodný pre aplikovanie v podmienkach biosférických rezervácií, pretože rozvoj biosférických rezervácií nikdy nebude môct' byt' založený na progresívnom priemyselnom rozvoji, ale mal by byt' založený na využití mäkkých faktorov rozvoja v kombinácii s výnimočným prírodným potenciálom.

V prípade väčšieho územného celku, ktorý môžeme stotožnit' aj s územím biosférickej rezervácie, je základom rozvoja postupný rozvoj jeho jednotlivých menších súčastí, t. j. obcí, miest, regiónov. Skokan (2004, s. 13) uvádza, že "ekonomický a sociálny rozvoj je lokálny jav, ktorý sa rozvíja v určitom regionálnom prostredí. Národná ekonomika je potom súhrnom miestnych a regionálnych ekonomík, ktoré obsahuje". V kontexte rozvoja územného celku hovoríme o ekonomickom rozvoji a sociálnom rozvoji. V novších vymedzeniach tento pojem zahŕňa aj environmentálne a územno-technické aspekty rozvoja, ked’že rozvoj území je omnoho širší pojem a nemožno ho obmedzovat’ len na ekonomicko-sociálny rozmer.

Miestny ekonomický rozvoj, považovaný za najdôležitejší pilier rozvoja územia, predstavuje proces, ktorého ciel'om je tvorba vyššieho počtu diferencovaných pracovných príležitostí pre lokálnych obyvatel'ov a stimulácia ekonomických aktivít v spravovanom území 
s rozhodujúcou úlohou samosprávnej vlády a komunitných skupín, ktoré riadia svoje existujúce zdroje a vstupujú do nových partnerstiev so súkromným sektorom alebo navzájom medzi sebou. Zároveň zdôrazňuje potrebu rovnováhy medzi potrebami podnikov a sociálnymi a politickými potrebami komunity (Blakely, 1994; Swinburn, Goga, Murphy, 2004; OECD, 2008; Čapková, 2004; Hudec et al., 2009; Hamalová, Belajová 2011 a iní). Je to proces, pomocou ktorého partneri z verejného, podnikatel'ského a mimovládneho sektora spoločne pracujú na tvorbe lepších podmienok pre hospodársky rast a tvorbu zamestnanosti““ (Swinburn, Goga, Murphy, 2004, s. 12).

V literatúre sa len zriedkavo stretávame s jednoznačnou definíciou sociálneho rozvoja. Benčo (2000) zhrnul obsah pojmu rozvoj do dvoch názorových prúdov. Prvý definuje sociálny rozvoj ako rozvoj takých spoločenských činností, ktoré uspokojujú potreby súvisiace $\mathrm{s}$ rozvojom osobnosti človeka (napr. materiálne potreby l’udí, sociálne potreby, potreby vzdelávania, kultúrne potreby a pod.). Druhý prúd vymedzuje sociálny rozvoj ako rozvoj l’udských zdrojov, školstva, vzdelania, bývania, životného prostredia a pod. Na základe týchto vymedzení definuje sociálny rozvoj ako "systém spoločenského rozvoja, ktorého prvky sú spojené s prácou a životom l’udí a uspokojovaním reprodukčných a rozvojových potrieb človeka. Tieto prvky sú vo vzájomnej interakcii nielen medzi sebou navzájom, ale i s prvkami systému ekonomického i vedecko-technického rozvoja."

Sociálny rozvoj sa spája aj so sociálnou infraštruktúrou, nakol'ko vytvára podmienky pre všestranný rozvoj človeka a uspokojovanie jeho životných potrieb. Tvrdoň, Hamalová a Žárska (1995, s. 37) charakterizujú sociálny rozvoj ako rozmiestnenie sociálnej infraštruktúry, ktorá v sebe zahŕňa byty, zariadenia obchodu a stravovania, zdravotnícke zariadenia, školské a výchovné zariadenia, vedecké, výskumné a projektové zariadenia, kultúrne zariadenia, administratívno-správne zariadenia, rekreačné a športové zariadenia.

Samostatnou kategóriou je územný rozvoj, ktorý sa spája s územným plánovaním, pričom územný rozvoj je predmetom územného plánovania. Meier a Čtyroký (2000, s. 59) rozumejú pod pojmom územný rozvoj "ciel’avedomé zhodnocovanie územia, t. j. zámernú zmenu spôsobu využívania územia a stavieb v ňom a/alebo intenzitu jeho využívania tak, aby sa zvýšil úžitok (výnos)". Uvedení autori taktiež vymedzujú niekol'ko základných subjektov, ktoré sa podiel'ajú na územnom rozvoji. Sú to napr. stavebníci, investori, developeri, komerční podnikatelia, verejné subjekty, neziskové subjekty a mnoho d’alších subjektov. Ďalej uvádzajú, že k zodpovednému rozhodnutiu tieto subjekty potrebujú informácie predovšetkým o trhu, o území, o finančnej a právnej oblasti a o právnych vzt’ahoch. 
V rozvoji územia je potrebné kombinovat' jednotlivé prístupy a prepájat' ich. Prostredníctvom územného plánovania sa zabezpečuje čo najefektívnejšie využívanie územia a rozloženie jednotlivých aktivít. To ovplyvňuje ekonomický rozvoj, rozsah finančných prostriedkov územia a kvalitu zabezpečovaných verejných služieb a tým aj sociálny rozvoj a kvalitu života obyvatel'ov. Dlhodobé sústredenie sa na zisk by viedlo k sociálnym problémom, avšak na riešenie environmentálnych, územných, či sociálnych problémov sú nevyhnutné finančné prostriedky. V tomto smere sa zdôrazňuje aj trvalá udržatel'nost' rozvoja, to znamená rozvojom súčasnej generácie neobmedzit' blaho budúcej generácie. Udržatel'ný rozvoj predstavuje synergiu hospodárskej, sociálnej a environmentálnej udržatel'nosti, ktoré odrážajú základné funkcie manažmentu územia (Žárska, 2007).

Základom úspešného napredovania územia je uplatňovanie strategického prístupu k jeho rozvoju. Strategické plánovanie predstavuje proces tvorby a udržiavania strategickej rovnováhy medzi ciel’mi a možnost’ami územia vo vzt’ahu k meniacim sa trhovým príležitostiam a celospoločenským potrebám (Kita, 2002; Vaňová, 2006). Ide o systémový a integrovaný prístup k rozvoju územia, ktorý vytvára príležitost' zvýšit' efektivitu a posilnit' väzby, ktoré by mali fungovat' navzájom, s ciel'om dosiahnut' synergiu, stimulovat' koordináciu v území, a tak zlepšit' vládnutie prostredníctvom participácie subjektov pri definovaní a implementácii rozvojovej verejnej politiky (Dente, 2014). V reálnych podmienkach území ide o konkrétne plánovacie dokumenty, ktoré riešia rozvoj rôznych oblastí života v území.

\section{Materiál a metódy skúmania}

Ciel'om príspevku je definovat' podstatu a špecifiká biosférických rezervácií v Slovenskej republike a charakterizovat' problémové oblasti ich fungovania.

V príspevku najprv na základe rešerše domácich a zahraničných vedeckých a odborných zdrojov vymedzujeme podstatu biosférickej rezervácie vo vzt’ahu k rozvoju územia. Tieto východiská následne analyzujeme a porovnávame saktuálnou situáciou, vymedzením a postavením biosférických rezervácií v Slovenskej republike a na základe metód syntézy a generalizácie identifikujeme problémové oblasti ich d’alšieho rozvoja.

Pri spracovaní príspevku využívame informácie získané z primárnych a sekundárnych zdrojov. Na základe preskúmania sekundárnych zdrojov - medzinárodných a národných dokumentov, ktoré sa venujú problematike biosférických rezervácií sme vymedzili pojem a podstatu biosférických rezervácií. Primárnym zdrojom informácií boli štruktúrované rozhovory s manažérmi štyroch biosférických rezervácií v Slovenskej republike - Slovenský kras, Pol’ana, Východné Karpaty a Tatry, ale aj skúsenosti predsedníčky Slovenského výboru 
pre program Človek a biosféra. Na ich základe sme vymedzili špecifiká biosférických rezervácií na Slovensku a ich problémové oblasti.

\section{Výsledky a diskusia}

Implementácia Programu UNESCO MAB je v Slovenskej republike koordinovaná prostredníctvom Slovenského výboru pre program Človek a biosféra, ktorý bol ustanovený dňa 9. marca 1993 ako poradný orgán ministra zahraničných vecí Slovenskej republiky. Je organizačnou súčast'ou Slovenskej komisie pre UNESCO, ktorá spadá pod Ministerstvo zahraničných vecí a európskych záležitostí SR.

V SR boli za biosférické rezervácie uznané Slovenský kras (1977), Pol’ana (1990), Východné Karpaty (1992), Tatry (1992). Biosférická rezervácia Tatry a Biosférická rezervácia Východné Karpaty sú cezhraničnými biosférickými rezerváciami. V zmysle $§ 28 \mathrm{~b}$ ods. 1 zákona č. 543/2002 Z. z. o ochrane prírody a krajiny v znení neskorších predpisov, biosférické rezervácie sú územiami medzinárodného významu. Všetky štyri sú súčasne vel'koplošnými chránenými územiami (3 sú národným parkom a 1 chránenou krajinnou oblast’ou). Avšak, $\mathrm{v}$ dôsledku neznalosti poslania a významu biosférických rezervácií často dochádza k vnímaniu biosférickej rezervácie ako d’alšej kategórie chráneného územia a s tým súvisiacimi obmedzeniami, či zákazmi. Biosférické rezervácie nie sú typické chránené územia, sú to modelové územia, kde ochrana prírodných hodnôt je podporovaná spôsobmi udržatel'ného využívania krajiny človekom. Zároveň by takýto prístup mal vlastníkom a užívatel'om, ktorí $\mathrm{v}$ týchto územiach uchovávajú kultúrne tradície a prírodné hodnoty, zaručovat' $\mathrm{v}$ praxi kompenzácie zo strany štátu.

Biosférická rezervácia Slovenský kras je najväčšou krasovou oblast'ou plošinového typu v strednej Európe na juhovýchode Slovenska, na hranici s Mad’arskom. Ide o významné územie z hl'adiska výskytu geologických, geomorfologických javov a zdrojov podzemných vôd z hl'adiska výskytu jedinečných druhov fauny a flóry. Celková plocha biosférickej rezervácie Slovenský kras je 74500 ha. Krasová krajina sa vyznačuje nielen reliéfom a podložím, ale aj osobitnou hydrológiou. V Slovenskom krase je známych 1300 jaskýň, ktoré sú od roku 1995 spolu s jaskyňami susediaceho krasu Aggtelek v Mad’arsku zapísané do Zoznamu svetového dedičstva UNESCO pod názvom Jaskyne Slovenského a Aggteleckého krasu. Rôznorodost' biotopov Slovenského krasu a vel’mi rozmanitá vegetácia odrážajú jeho klimatické a geologické podmienky a geomorfologicky odlišné krasové javy. Jej flóra je jednou z najbohatších v strednej Európe. Hustota osídlenia je vel’mi nerovnomerná, ale vo všeobecnosti nízka. Väčšinu 
lesov tvoria porastové dreviny pochádzajúce z opakovane rezaných listnatých stromov a lesné plantáže pestované lesníkmi. Na náhorných plošinách prevláda lesníctvo $\mathrm{s}$ pol'nohospodárstvom. Osady a súvisiace hospodárske činnosti sa sústred’ujú na povodia a údolia riek.

Na území BR žije približne 50000 obyvatel'ov, dotknutých je spolu 50 katastrov obcí $\mathrm{v}$ troch okresoch. Jadrová a nárazníková zóna $\mathrm{BR}$ sa $\mathrm{z}$ väčšej časti prekrýva s územím národného parku i jeho ochranného pásma. Vlastné územie NP je bez osídlenia, 7 obcí leží v ochrannom pásme NP, ostatné po jeho obvode. Prechodná zóna je v prevažnej miere mimo chráneného územia.

Región má priemyselno-vidiecky charakter a viac l'udí je zamestnaných $\mathrm{v}$ pol'nohospodárstve ako v priemysle. Pol’nohospodárska výroba je už výhradne iba súkromným sektorom od malých rodinných fariem, súkromne hospodáriacich rol’níkov, družstevných spoločností až po niekol'ko obchodných spoločností. Významným zamestnávatel'om sú úrady štátnej a verejnej správy. V území je slabo rozvinutá infraštruktúra cestovného ruchu. Je potrebné ju rekonštruovat', dobudovat' a zvýšit' kvalitu poskytovaných služieb.

Oblast' BR SK je postihnutá ekonomickou depresiou, v dôsledku vyššej emigrácie obyvatel'stva a nízkeho prirodzeného prírastku, čo výrazne ovplyvňuje sociálne pomery. Mimoriadne negatívnym javom v území je aj nezamestnanost'. Je to územie s vysokou mierou nezamestnanosti, zaradené je v rámci politiky vlády SR medzi najmenej rozvinuté okresy.

Biosférická rezervácia Pol'ana predstavuje najvyššie sopečné pohorie na Slovensku. Celá oblast' je súčast'ou karpatského oblúka. Vplyvom jeho vysunutia smerom na juh a výškovému rozpätiu takmer $1000 \mathrm{~m}$ sa na relatívne malom území vyskytujú teplomilné, ako aj horské druhy rastlín a živočíchov. Unikátny geologický a geomorfologický charakter tejto oblasti je výsledkom sopečnej činnosti v období pred 13 - 15 miliónmi rokov. Lesy pokrývajú približne 85\% plochy. Pre Pol'anu sú typické vel'ké bukové lesy, jedl'ové bučiny a kopcovité lesné spoločenstvá. V minulosti odlesnené oblasti, dnes predstavujú spoločenstvá lúk a pasienkov s výskytom cennej vegetácie rašelinísk a podmáčaných lúk. Typické sú horské a subalpínske druhy tráv. Skalné spoločenstvá zvyšujú celkovú biodiverzitu oblasti. Ojedinelú krajinnú štruktúru zvýrazňujú tradičné drevené domy, stodoly, zemiakové pivnice, mal'ované drevené kríže a d’alšie l’udové umenie. Súčasná rozloha biosférickej rezervácie Pol’ana je 24 158,23 ha (Fabriciusová, Miňová, 2016).

Biosférická rezervácia Pol'ana zahŕňa 13 obcí - Čierny Balog, Detva, Dúbravy, Hriňová, Hrochot', Hronec, Lubietová, Očová, Poniky, Povrazník, Sihla, Strelníky, Valaská s takmer 
42000 obyvatel'mi. Z toho 3900 l'udí trvalo žije vo vymedzených hraniciach biosférickej rezervácie. Obyvatelia žijú prevažne na vidieku. V území prevláda slovenská národnost' doplnená v menšom počte českou, mad'arskou a pol'skou. BR Pol'ana sa vyznačuje nízkou populáciou, ktorá je sústredená v prechodovej zóne južnej časti územia.

Hlavnými hospodárskymi aktivitami sú lesníctvo a pol'nohospodárstvo. V území sa využívajú pre potreby pol’nohospodárstva kone a tradičné pol’nohospodárske nástroje. Pol’nohospodárstvo neponúka dostatočné množstvo pracovných príležitostí. Jednotliví farmári, ktorí obhospodarujú pol’nohospodársku pôdu $\mathrm{v}$ BR, pracujú $\mathrm{v}$ náročných podmienkach. Pol'nohospodári a lokálni producenti podliehajú kontrole štátnych orgánov. Marketing lokálnych produktov závisí od dopytu zo strany štátu alebo iných spracovatel’ov potravín. Malé výmery ornej pôdy spôsobujú, že farmári nemajú nárok na niektoré pol'nohospodárske dotácie. Naopak význam turizmu ako hospodárskeho odvetvia rastie. Zástupcovia samospráv a miestni obyvatelia BR Pol'ana majú svoje zastúpenie v Koordinačnej rade biosférickej rezervácie Pol’ana. Územie biosférickej rezervácie patrí z hl'adiska folklórneho a etnografického dedičstva k najvýraznejším regiónom Slovenska. Prezentácia tradičných regionálnych tancov, piesní, krojov a hudby sa každoročne koná v rámci Dňa otvorených dverí BR Pol'ana. Podujatie pre širokú verejnost' prezentuje výsledky vzájomnej spolupráce všetkých členov KR BR Pol’ana.

Biosférická rezervácia Východné Karpaty sa nachádza v najvýchodnejšej časti Slovenska na križovatke politických hraníc troch európskych krajín - Pol’ska, Slovenska a Ukrajiny. Je to prvá trojstranná biosférická rezervácia na svete, ktorú tvoria Národný park Poloniny (Slovensko), Bieščadský národný park, Park Krajobrazowy Doliny Sanu, Ciśniańsko-Wetliński Park Krajobrazowy (Pol'sko) a Užanský národný prírodný park, Nadsyansky Regional Landscape Park (Ukrajina). Územie slovenskej časti BR sa prekrýva s územím Národného parku Poloniny. 28. júna 2007 boli do Zoznamu svetového dedičstva UNESCO zapísané Karpatské bukové pralesy nachádzajúce sa $\mathrm{v}$ slovenskej časti BR ako cezhraničná sériová nominácia (Ukrajina/Slovensko). Táto lokalita svetového dedičstva sa postupne rozširovala o komponenty v d'alších európskych krajinách, pričom posledné rozšírenie sa uskutočnilo v roku 2021. Momentálne figuruje po názvom Staré bukové lesy a bukové pralesy Karpát a iných regiónov Európy. Celková výmera BR v súčasnosti predstavuje 40 689, 92 ha. Zachovalé vegetačné bukové lesy, kosené lúky, pasienky a špeciálne horské lúky ,poloninské lúky“ - predurčujú prirodzenú rozmanitost’ biocenóz. Lesy pokrývajú viac ako $90 \%$ BR a viac ako polovica lesov BR je súkromných. Lesníctvo je dominantnou hospodárskou činnost'ou a predovšetkým poskytuje príležitosti pre pracovné miesta s nízkou kvalifikáciou. 
Obhospodarovanie lesov je jednou z činností, ktoré majú najvýznamnejší vplyv na celkové územie a tiež na život miestnych komunít. Pol’nohospodárska pôda predstavuje 6,4 \% územia BR (1 895 ha). V skutočnosti ide výlučne o trvalé trávne porasty. Drobné časti pozemkov pri sídlach, evidovaných v katastri ako orná pôda, sú totiž odpradávna väčšinou zarastené trávou. Pol'nohospodárstvo je zamerané hlavne na chov zvierat, a preto sa produkčná pôda využíva najmä na pestovanie krmív ako zelené krmivo, senáž alebo siláž a ako pasienky. Len malá čast' pôdy sa využíva na pestovanie iných plodín. Počet hospodárskych zvierat a produkcia mlieka sa v referenčnom období výrazne znížili. Rozloha obrábanej pôdy si zachováva viac-menej stabilný stav. Je to najmä vd’aka dotačným schémam v rámci Programu rozvoja vidieka. V súčasnosti sú v prechodovej zóne 3 hospodárske dvory (v obciach Ulič, Zboj a Runina).

Z hl'adiska cestovného ruchu je BR Východné Karpaty jednou z najatraktívnejších častí Slovenska (25 000 návštevníkov ročne) Č́́sla však ukazujú stále rastúci trend. Približne $90 \%$ návštevníkov pochádza zo Slovenska, Českej republiky a Pol’ska. Miestne samosprávy chápu význam turizmu v kontexte budúceho rozvoja regiónu a ako alternatívnu príležitost’ príjmu. V spolupráci so Správou národného parku sa snažia zlepšit’ infraštruktúru cestovného ruchu, ktorá bola v minulosti dost’ málo rozvinutá. Takmer všetky ubytovacie zariadenia sú súkromné. (Gič a kol., 2017).

Biosférická rezervácia Tatry sa nachádza v severnej časti Slovenskej republiky. Územie biosférickej rezervácie zahŕňa dva národné parky a ich ochranné pásma ležiace na oboch stranách slovensko-pol'skej hranice. Slovenskú čast' tvorí národný park Tatry - Tatranský národný park (TANAP) a pol'skú stranu tvorí súčasný národný park Tatry - Tatrzański park Narodowy (TPN). Jedinečnost' a malebnost' prírodných podmienok biosférickej rezervácie spočíva predovšetkým v ich vysokohorskom charaktere. Odráža sa to vo výraznej diferenciácii krajiny, ktorá závisí najmä od orografického usporiadania, mohutnosti, rozsahu a výšky pohoria. Biosférickú rezerváciu tvoria Východné Tatry, Západné Tatry, Podtatranská kotlina a Podtatranská brázda. Po úprave hraníc v rámci periodického hodnotenia v roku 2017 BR Tatry zaberá územie o rozlohe 101819,05 ha. Rôznorodost' územia umocňujú zachované znaky tradičnej l'udovej kultúry. L’udová kultúra a folklór tohto regiónu majú vel’a spoločného, ale výrazne sa líšia aj od susedných regiónov v Pol'sku a na Slovensku. Tradičné využitie biosférickej rezervácie je pol’nohospodárstvo a lesníctvo, kúpel’níctvo a športovo rekreačné aktivity. Od začiatku historického rozvoja bolo pol'nohospodárstvo spojené s chovom hovädzieho dobytka a oviec. Cestovný ruch sa začal objavovat’ od roku 1871. 
K roku 2017 bol v území BR Tatry zaznamenaný celkový počet obyvatel'ov 128570 . Tento údaj je uvádzaný za slovenskú čast' BR Tatry. Populácia má vel'mi úzku väzbu na územie BR, o to viac sa rozvojové plány v týchto mestách musia zameriavat' súčasne na územie biosférickej rezervácie a národného parku. Špecifikom je mesto Vysoké Tatry, ktoré je konglomerátom niekol'kých obcí ako hlavných turistických stredísk nachádzajúcich sa v nárazníkovej zóne BR Tatry. V meste je dlhodobo zaznamenávaný neustály úbytok trvalého obyvatel'stva (zdroj Mestský úrad mesta Vysoké Tatry). Mladí l'udia sa radšej usadzujú v prechodnej zóne, mimo turistických centier, kde je dobre rozvinutá infraštruktúra pre každodenný život. Prieskumy ukazujú, že v sezóne navštívi BR Tatry 3,5 - 4 mil. turistov.

Horská krajina so strediskami cestovného ruchu je prechodom medzi kultivovanými a prírodnými čast’ami regiónu, vrátane mnohých druhov lesov, s vel'kou biotickou diverzitou. Cestovný ruch je hlavným odvetvím zamestnávajúcim miestnych l'udí, nasleduje lesníctvo a do určitej miery pol’nohospodárstvo. Pol’nohospodári a lesníci predávajú svoje produkty a môžu dostávat' aj dotácie na obhospodarovanie pôdy v chránenom území. Spomínané činnosti sú zdrojom obživy tunajších obyvatel'ov. Miera nezamestnanosti v rámci BR sa pohybuje od cca 8 - $15 \%$. Ďalšími dôležitými zdrojmi príjmov pre obce je daň z ubytovania, daň z pozemkov a nehnutel'ností. Niektorí vlastníci pôdy si pôdu prenajímajú. Užívatelia, ktorými sú väčšinou firmy obhospodarujúce lesnú a pol’nohospodársku pôdu platia nájomné miestnym l’ud'om, vrátane dôchodcov. Pomerne významnými užívatel’mi lesov sú „urbariáty“. Ide o špecifickú formu spoločenstva vlastníkov pôdy. í. Členmi týchto urbariátov sú často všetci obyvatelia konkrétnej obce. Členom sa vyplácajú dividendy a zvyčajne dostávajú aj palivové drevo. (Správa z periodického hodnotenia biosférickej rezervácie Vysoké Tatry, 2013).

\section{Problémy fungovania BR}

Pôsobenie biosférických rezervácií v podmienkach Slovenskej republiky je dlhodobo spojené s viacerými charakteristickými problémami, ktoré možno rozdelit' do troch skupín.

Prvá skupina problémov súvisí s nedostatočným uznaním postavenia biosférických rezervácií v podmienkach SR ako území medzinárodného významu a ich úlohy z hl'adiska napĺn̆ania medzinárodných dohovorov a ciel’ov udržatel'ného rozvoja, ktoré sú aktuálne sformulované v rámci Agendy 2030.

Aj ked’ prvá biosférická rezervácia vznikla v roku 1977, až do roku 2014 neboli biosférické rezervácie v podmienkach Slovenska definované v žiadnom platnom právnom predpise. Aj ked’ novelou zákona NR SR č. 543/2002 o ochrane prírody a krajiny v znení neskorších predpisov Z. z. účinnej od 1.1.2014 sa situácia zmenila, a biosférickým rezerváciám bol stanovený štatút 
území medzinárodného významu, stále chýba podrobnejšie určenie ich pôsobnosti a kompetencií vo vzt'ahu k ostatným subjektom v ich území, ako aj určenie ich jej inštitucionálnej samostatnosti. V súčasnosti manažment biosférických rezervácií koordinuje Štátna ochrana prírody Slovenskej republiky v spolupráci s pracovníkmi správ národných parkov a chránených krajinných oblastí, ktorých súčast'ou sú aj biosférické rezervácie. Zodpovednost' za vel'koplošné chránené územie je preto úzko spätá s plnením úloh v rámci agendy biosférickej rezervácie, ktorá pokrýva spravidla rozlohou väčšie územie, väčšie množstvo zainteresovaných subjektov, a tým aj náročnejšie riadenie jeho rozvoja. Nové teoreticko-empirické poznatky a skúsenosti zo zahraničia (napr. Švajčiarska) vedú k potrebe ich komplexného systémového, inštitucionálneho, legislatívneho i finančného uchopenia, najmä v krajinách, kde sa neprejavuje prirodzene významnost' postavenia tohto typu území a ich úloha v zachovaní biodiverzity.

Druhým problémom je absentujúci dlhodobý strategický prístup k rozvoju biosférických rezervácií. Vzhl’adom na to, že biosférickým rezerváciám nie je venovaná adekvátna pozornost' zo strany riadiacich orgánov, vedie to k nesystémovej starostlivosti o územie biosférických rezervácií, ako aj ich rozvoju. Biosférické rezervácie pod správou Štátnej ochrany prírody SR nemajú dostatočné kapacity na to, aby mohli realizovat' rozvojové aktivity strategicky. Biosférickým rezerváciám chýbajú kl'účové rozvojové dokumenty, riadiace dokumenty a akčné plány, plány marketingovej komunikácie, ako aj metodické postupy ich zostavovania. Aj ked’ na medzinárodnej úrovni existujú technické smernice UNESCO, ktoré tvoria rámec pre tvorbu uvedených dokumentov prispôsobených podmienkam konkrétnej krajiny, v podmienkach Slovenskej republiky takéto národné smernice $\mathrm{v}$ oblasti riadenia a pôsobenia biosférických rezervácií chýbajú.

Z hl'adiska sledovania rozvoja biosférických rezervácií, biosférické rezervácie podliehajú pravidelnému periodickému hodnoteniu, ktoré zohl'adňuje stav plnenia kritérií Rámcového štatútu Svetovej siete biosférických rezervácií (Článok 4). Ciel’om periodického hodnotenia je umožnit' Medzinárodnej koordinačnej rade (ICC MAB) posúdit', či konkrétna biosférická rezervácia plní kritériá stanovené v článku 9 Štatutárneho rámca, a obzvlášt' svoje tri funkcie . Toto posudzovanie môže trvat' aj viac rokov, ak v správach z periodického hodnotenia nie sú uvedené všetky potrebné informácie. Hodnotenie je vykonávané raz za desat' rokov prostredníctvom vypracovania správy, ktorú Sekretariátu Programu Človek a biosféra predkladá Slovenský výbor MAB v spolupráci s príslušnými organizačnými jednotkami Štátnej ochrany prírody Slovenskej republiky. Správa o stave plnenia je posudzovaná Poradným výborom pre biosférické rezervácie, ktorý rozhoduje o jej odporúčaní pre ICC MAB. ICC MAB d'alej preveruje vypracované správy členských štátov a vydáva následné odporúčania a 
rozhodnutia ohl'adom vyňatia biosférických rezervácií zo Svetovej siete biosférických rezervácií. Niektoré krajiny majú v súčasnosti zavedené „strednodobé hodnotenia“, ktoré monitorujú výkonnost' biosférických rezervácií na národnej úrovni každých pät' rokov. Slovenské biosférické rezervácie ukončili ostatné periodické hodnotenia nasledovne: Pol’ana v roku 2016, Tatry, Východné Karpaty a Slovenský kras v roku 2018.

Na základe teoretických východísk, a empíria to potvrdzuje, je pre hodnotenie rozvoja biosférickej rezervácie nevyhnutné stanovit' ciele a priority rozvoja územia pre dlhšie časové obdobie, konkrétny plán aktivít a najmä meratel'né ukazovatele, na základe ktorých je možné hodnotit' naplnenie stanovených ciel'ov. Aj ked' k periodickému hodnoteniu biosférických rezervácií dochádza, je otázne, akým spôsobom sa dá v súčasnosti hodnotit' ich ekonomický a sociálny rozvoj, ak ciele $\mathrm{v}$ týchto oblastiach nie sú jednoznačne stanovené a pracovníci zodpovední za tvorbu hodnotiacich správ nie sú odborníkmi v tejto oblasti. Na druhej strane však aj skúsenosti zo zahraničia potvrdzujú, že periodické hodnotenie je vnímané častejšie ako administratívna povinnost', a menej ako príležitost' pre manažérov biosférických rezervácií hodnotit' svoje aktivity a hl'adat' kreatívne nápady pre usmernenie rozvoja spravovaného územia (Bouamrane, Dogsé, Price, 2020).

Tretím problémom je nedostatočné poznanie území biosférických rezervácií v prepojení na sociálno-ekonomické aspekty rozvoja s dôrazom na zachovanie biodiverzity v synergii s človekom. Uvedený absentujúci strategický prístup k rozvoju biosférických rezervácií je úzko prepojený aj s nedostatočnou analýzou biosférických rezervácií, ani nie tak z pohl’adu prírodných podmienok, ale najmä z pohl’adu socio-ekonomického, sociodemografického a inovačného potenciálu. Predpokladom poznania územia je vypracovanie detailnej analýzy, na základe čoho je možné vytvorit’ návrh d’alšieho rozvoja územia s ohl'adom na rozvoj takých ekonomických, sociálnych a najmä dlhodobo udržatel’ných aktivít, ktoré budú v symbióze so zachovaním prírodného bohatstva v skúmaných územiach a napĺn̆aním ciel’ov Agendy 2030. V súčasnosti sú detailne preskúmané najmä prírodné podmienky jednotlivých biosférických rezervácií v Slovenskej republike. Predstavitelia biosférických rezervácií poukazujú na nedostatky $\mathrm{v}$ rámci skúmania ostatných zložiek potenciálu, jednak z dôvodu nedostatku l'udských zdrojov, ako aj z hl'adiska ich nedostatočnej kvalifikácie a zručností v oblasti sociálno-ekonomickej analýzy územia.

Jednotlivé identifikované problémové oblasti nie je zároveň možné od seba oddelit', vzájomne sú prepojené a ovplyvňujú sa. Na základe toho sa dá predpokladat', že akákol'vek pozitívna zmena, či riešenie aj čiastkového problému sa výrazne prejaví svojím dopadom v území biosférickej rezervácie, ale aj v jej riadení. Zároveň je zrejmé, že komplexné riešenie 
identifikovaných problémov si vyžaduje realizáciu postupných krokov, viac i menej náročných, založených na princípoch strategického manažmentu a dopady riešenia je tak možné očakávat' až v dlhšom časovom horizonte.

\section{Záver}

Ciel’om príspevku bolo definovat' podstatu a špecifiká biosférických rezervácií $\mathrm{v}$ Slovenskej republike a charakterizovat' problémové oblasti ich fungovania.

Môžeme konštatovat', že aj ked' problematika biosférických rezervácií a ich rozvoja je vel'mi aktuálna, v podmienkach Slovenskej republiky si jednak predstavitelia štátu, ale aj širšia verejnost' neuvedomujú potrebu zachovania biodiverzity v územiach a systémovej podpory tohto špecifického typu území. V prípade, že sa podarí úspešne naplnit' ciele projektu APVV20-01-08 Implementácia Agendy 2030 prostredníctvom biosférických rezervácií, pomôže to potenciálne zlepšit’ situáciu v tejto oblasti. Zámerom tohto projektu je na základe spolupráce Univerzity Mateja Bela, Ústavu krajinnej ekológie Slovenskej akadémie vied a Štátnej ochrany prírody Slovenskej republiky vytvorit' návrh udržatel'ného inštitucionálneho, finančného a legislatívneho modelu fungovania biosférických rezervácií v podmienkach Slovenskej republiky a návrh východísk ich strategického rozvoja na základe analýzy potenciálu územia $\mathrm{v}$ kontexte napíňania ciel'ov Agendy 2030, teórie odolnosti, zahraničných skúseností a príkladov dobrej praxe.

Grantová podpora: Príspevok prezentuje čiastkové výsledky projektu APVV-20-01-08 Implementácia Agendy 2030 prostredníctvom biosférických rezervácií.

\section{Zoznam použitej literatúry}

[1] Batisse, M. (1985). Action Plan for Biosphere Reserves. [Akčný plán pre biosférické rezervácie] Environmental Conservation 12(1): 17 - 27. doi: https://doi.org/10.1017/ S0376892900015113.

[2] Benčo, J. (2001). Metodológia vedeckého výskumu. Bratislava: Iris.

[3] Blakely, E. J. (1994). Planning local economic development: Theory and practice. [Plánovanie miestneho ekonomického rozvoja: Teória a prax]. Thousand Oaks: Sage.

[4] Bouamrane, M., Dogsé, P., Price, M. F. (2020) Biosphere reserves from Seville, 1995, to building a new world for 2030 [Biosférické rezervácie od Sevily, 1995, po budovanie nového sveta do roku 2030]. In: Reed, M. G., Price, M. F. (eds.) UNESCO Biosphere Reserves. Supporting Bicultural Diversity, Sustainability and Society. Oxon: Routledge. 
[5] Bridgewater, P. (2002). Biosphere reserves: Special places for people and nature. Environmental Science \& Policy, 5(1), 9-12. doi: 10.1016/S1462-9011(02)00018-7.

[6] Buček, M. (1992). Priestorová ekonomika. Bratislava: Rektorát Ekonomickej univerzity v Bratislave.

[7] Čapková, S. (2004). Rozvoj miestnej ekonomiky. Banská Bystrica: UMB Ekonomická fakulta.

[8] Dente, B. (2014). Towards a typology of local development policies and programmes [K typológii politiky miestneho rozvoja a programov]. Local Economy, 29(6-7), 675-686.

[9] Fabriciusová V., Slávik D. (2010). 20 rokov programu UNESCO človek a biosféra v CHKO Pol'ana. In: Biosférické rezervácie na Slovensku. VIII. Zborník referátov. Vydavatel'stvo Technickej univerzity vo Zvolene, 11-14.

[10] Fabriciusová, V., Miňová, L. (2016). Chránená krajinná oblast’ a Biosférická rezervácia Pol’ana): Skúsenosti z 25-ročného spravovania územia Biosférickej rezervácie Pol’ana a predstavenie príkladov dobrej praxe.

[11] Gič, M., Perinaj, M., Guziová, Z. (2017). Periodic review for the East Carpathians Biosphere Reserve - Slovak part [Správa z periodického hodnotenia biosférickej rezervácie Východné Karpaty - slovenská čast'].

[12] Hamalová, M., Belajová, A. (2011). Komunálna ekonomika a politika. Bratislava: Sprint dva.

[13] Hudec, O. et al. (2009). Podoby regionálneho a miestneho rozvoja. Košice: Ekonomická fakulta TU.

[14] Kita, J a i. (2002). Marketing. 2. vyd. Bratislava: IURA Edition.

[15] Meier, K., Čtyroký, J. (2000). Ekonomika uzemního rozvoje. Praha: Grada Publishing.

[16] Maier, G., Tödtling, F. (1997). Regionálna a urbanistická ekonomika. Viedeň : Springer Verlag,

[17] OECD Insights (2008). Sustainable Development: Linking Economy, Society, Environment [Udržatel'ný rozvoj: Prepojenie ekonomiky, spoločnosti, životného prostredia]. Dostupné na: www.oecd.org/insights.

[18] Skokan, K. (2004). Konkurenceschopnost, inovace a klastry v regionálním rozvoji. Ostrava: Repronis.

[19] Správa z periodického hodnotenia biosférickej rezervácie Vysoké Tatry (2013).

[20] Swinburn, G., Goga, S., Murphy, F. (2004). Úvod do miestneho hospodárskeho rozvoja. Svetová Banka. 
[21] Švihlová, D. (2004). Trvalo udržatel’ný rozvoj na miestnej úrovni. Banská Bystrica: Ekonomická fakulta Univerzity Mateja Bela.

[22] Štatút Slovenského výboru pre Program UNESCO Človek a biosféra. (2017).

[23] Tvrdoň, J., Hamalová, M., Žárska, E. (1995). Regionálny rozvoj. Bratislava: Ekonóm.

[24] Vaňová, A. (2006). Strategické marketingové plánovanie rozvoja územia. Banská Bystrica: UMB Ekonomická fakulta.

[25] Vološčuk, I. (1998). Biosférické rezervácie Slovenska. Poprad: SLZA.

[26]Zákon NRSR č. 543/2002 Z. z. o ochrane prírody a krajiny v znení neskorších predpisov, [27]Žárska, E. (2007). Komunálna ekonomika a politika. Bratislava: Ekonóm.

[28] UNESCO (1996). Biosphere reserve: The Seville Strategy and the Staturory Framework of the World Network. [Biosférické rezervácie: Sevilská stratégia a štatutárny rámec svetovej siete]

[29] UNESCO (2021). UNESCO's commitment to biodiversity. [Záväzok UNESCO k biodiverzite]. Dostupné na: https://en.unesco.org/themes/biodiversity.

[30] UNESCO (2021). Bisophere reserves [Biosférické rezervácie]. Dostupné na: https://en.unesco.org/biosphere/wnbr.

Adresa autorov: Katarína Vitálišová, Doc. Ing. PhD., Ekonomická fakulta Univerzity Mateja Bela v Banskej Bystrici, Tajovského 10, 97401 Banská Bystrica, katarina.vitalisova@umb.sk Lucia Miňová, Mgr., Štátna ochrana prírody SR, Správa CHKO Pol'ana, J. M. Hurbana 20, 960 01 Zvolen, lucia.minova@sopsr.sk; Anna Vaňová, Doc. Ing. PhD., Ekonomická fakulta Univerzity Mateja Bela v Banskej Bystrici, Tajovského 10, 97401 Banská Bystrica, anna.vanova@umb.sk 